\title{
Group Therapy Perception among Parents of ASD Children Attended at SLT Unit in a Reputed Rehabilitation Centre
}

\section{Sharmin Sultana ${ }^{1}$, Nurvin Jahan Asha ${ }^{2}$, Mohammad Kamrujjaman ${ }^{\star, \dagger}{ }^{3}$, Boby Akter $^{4}$, Monjur Alam ${ }^{5}$, H.M. Abubakar Siddik ${ }^{6}$}

\author{
${ }^{1}$ Clinical Speech and Language Therapist, Centre for the Rehabilitation of the Paralysed (CRP), Dhaka \\ ${ }^{2}$ Clinical Speech and Language Therapist, Centre for the Rehabilitation of the Paralysed (CRP), Dhaka \\ ${ }^{3}$ Assistant Professor, State College of Health Sciences, Dhaka \\ ${ }^{4}$ Speech Therapist, National Institute of Neurosciences and Hospital, Dhaka \\ ${ }^{5}$ Clinical Speech and Language Therapist, Centre for the Rehabilitation of the Paralysed (CRP), Dhaka \\ ${ }^{6}$ Clinical Speech and Language Therapist, Centre for the Rehabilitation of the Paralysed (CRP), Dhaka
}

QDOI: https://doi.org/10.15520/jcmro.v2i10.207

Accepted 16-10-2019; Received 20-09-2019; Publish Online 17-10-2019

\author{
Reviewed By: \\ Dr. Kratika Daniel \\ Department: \\ Reviewer/CMRO
}

\begin{abstract}
Purpose: The purpose of this study is to explore the perception of parent about group therapy for children with autism spectrum disorder.

Methods: A qualitative research design was conducted in Centre for the Rehabilitation of the Paralysed (CRP) and all autism was assessed by Speech Language Therapist appointed in CRP. A number of 12 participants were used. A self-made question was used to collect data and research data were collected by questionnaire with tab record. Patient's consent was taken during data collection. The data collected from the interviewers were analyzed using content analysis.

Results: Parents explored different views about autism group therapy in speech and language therapy. Some clients think that speech therapy means learning to speak and understanding; therapy which is given in a group of 8 children; most of the parents gave both individual and group therapy for their children to CRP; Therapist worked to learn socialization, eye contact, sharing, functional play, music therapy for increasing attention. However, near about all of the patients had good prognosis but the patients noticed as complaint about the amount of time and days for a therapy session.

Conclusion: This research would help and also encourage the parents to take autism group therapy for children. For this study, everyone will know different types of group therapy and its effectiveness. Parent's perception might help to make necessary to help them to increase confidence in this challenging health care profession. So this study gives a significant massage that group therapy will be used meaningfully for the parents of autism children.
\end{abstract}

Key words: Autism Spectrum Disorder-Autism Group Therapy-Speech and Language Therapy-Centre for Rehabilitation of the Paralysed

\section{INTRODUCTION:}

Autism is a lifelong developmental disorder that affects the brain leads to find difficulty communicating and interacting with other people, such as playing, socializing with others

* Corresponding author.

$\dagger$ Email: kamrujjaman10@gmail.com more difficulties [1] [2]. It is a complex group of disorders that impaired socialization and reduce child interest in every activity [3]. Autism occurs about three or four times more frequently in boys than girls and more common in firstborn male. Around $40 \%$ of children with autism are unable to speak at all. The prevalence of autism identified 1 in 68 children ( 1 in 42 boys and 1 in 189 girls) [4]. In special education schools, 97 of 114 children were an autistic dis- 
order [5]. Children with Autism Spectrum disorder (ASD) face verbal and nonverbal communication difficulties, social interaction and play activities [1]. In nonverbal communication, children with ASD face difficulties in maintaining eye contact, pointing, joint attention and turn-taking [6]. Children with autism also face difficulty to use facial expression, vocal intonation, loudness etc. [7]. Michael \& powers (2000) [1] mentioned that Speech and Language therapist (SLTs) work on ASD with communication, receptive and expressive language, pragmatics, play behaviors, attention, voice, auditory memory, oral motor functioning, and articulation. Autism group therapy includes pretend play, joint attention, and imitation and play skills [8]. Group therapy for the patient with autism is a new treatment service in Bangladesh. It is not offered all over Bangladesh. If parents of autism child know about group therapy, they (autism child) will participate in it and they can lead more easilylife. Through this study the importance of group therapy highlighted and awareness will arise among the parents of autism children. It also helps to gain parents' attention towards group therapy for their children. Thus this study will help children with autism to get better treatment.

\section{MATERIALS AND METHODS:}

\subsection{Study design and Participants:}

In this study, the researchers used a qualitative phenomenological research design. The focus of this study was on the parents' perception on group therapy for the children ASD. According to Hicks (1999) [9], "Qualitative research is exploratory in nature by which researchers can gain insight into another person's view, opinions, feelings and beliefs within their own natural settings." A parent of group therapy with autism spectrum disorder (ASD) children attends in Centre for Rehabilitation of the Paralysed (CRP) pediatric outpatient unit at Savar, Dhaka, selected to conduct the study. The researchers took 12 participants as a sample group by using purposive sampling to represent the population group for this study. Theinvestigators took who completed minimum of two sessions in autism group therapy.

\subsection{Data collection:}

The researchers collected data through semi-structured, indepth interviews with an open-ended question. The interviewer explained the title and the aim of the study to promote the trust of the participants. The investigators used a consent form both in English and Bengali and took the participant's consent English and Bengali.

\subsection{Statistical analysis:}

The Investigators analyzed qualitative data by using content analysis. Transcripts made to transcribe into English. On the basis of the purpose of the study category and code were made to summarize it under keywords. During analysis, the whole transcript was read several times to identify the important issue that the participants said. These analyses were a process where the researchers analyzed the data by looking for repetitive words and concepts. The researchers were also identifying what the participants actually want to say. On the basis of what the participants wanted to say, the answer was categorized. Under this category the participant' responds were code. The last stages involved identify the actual theme interpretation of data.

\section{RESULTS:}

Table 1 reveals that most of the participants (P2, P3, P4, P5, P7, P8, P9, P10, P11 and P12) had similar kind of knowledge about the therapy of learning speaking. Participants (P10 and P11) are also said that the speech and language therapist works to understand with children. P-1 was not response and P-6 was not known about speech and language therapy. But, P-9 state that the therapist learns in her children in the pronunciation with speaking. Participants -8 stated that therapy means learning the object.

Table 2 indicates that maximum participants (P1, P7, P9, $\mathrm{P} 10$ and $\mathrm{P} 11)$ mentioned that the therapy which is given in a group of $8-10$ children and participants (P4, P5, P6, $\mathrm{P} 7$ and P12) also responds that the therapy which have many children with altogether. The minimum participants (P2 and P5) said that the therapy which given work together. Participants (P2 and P12) mentioned that the therapy which works together, at last P-3 and P-8 does not a response to autism group therapy.

Table 3 shows that six participants (P1, P2, P5, P7, $\mathrm{P} 11$ and $\mathrm{P}$ 12) mentioned: parents were a perception about group therapy previously. Another six participants (P4, P5, P6, P7 P9 and P11) mentioned that the therapist was informing the children mothers previously. Six Participants (P3, P4, P6, P8, P9 and P10) was also mentioned that parents were not the previous perception about autism group therapy.

Table 4 reveals that maximum participants (P1, P3, P4, P5, P6, P8, P10, P11 and P12) said that the therapy which given by one therapist is called individual therapy. But some participants (P2, P7 and P9) do not response about individual therapy in those questions.

Table 5 states that maximum participants (P1, P2, P3, $\mathrm{P} 4, \mathrm{P} 9, \mathrm{P} 10$, and $\mathrm{P} 11)$ mentioned that they gave in their child's both individual and group therapy. The minimum participants (P5, P6, P7 and P8) mentioned that they gave their children in individual therapy and $\mathrm{P}-12$ gives in group therapy.

On the Table 6 shows that eight participants (P2, P5, P7, $\mathrm{P} 8, \mathrm{P} 10, \mathrm{P} 11$, and P12) said that at first therapist learned social integration for introducing with all children. On the other side, seven participants (P1, P2, P3, P9, P10, P11, and $\mathrm{P} 12$ ) said that the therapist is told rhythms of group therapy for sound. Maximum 10 participants (P1, P2, P3, $\mathrm{P} 5$, and $\mathrm{P} 7-\mathrm{P} 12$ ) have also agreed to use music for increasing attention for their child and they are motivated those group therapy.

Table 7 shows that seven participants (P2-P4, P7, P8, $\mathrm{P} 11$, and $\mathrm{P} 12)$ are also agreed about the functional play 
Table 1. Category-1: Parents knowledge about speech and language therapy

\begin{tabular}{|c|c|c|c|c|c|c|}
\hline Code & $\begin{array}{l}\text { Therapy of } \\
\text { learning } \\
\text { object }\end{array}$ & $\begin{array}{l}\text { Therapy of } \\
\text { learning } \\
\text { speaking }\end{array}$ & $\begin{array}{l}\text { No } \\
\text { response }\end{array}$ & $\begin{array}{l}\text { Not } \\
\text { known }\end{array}$ & $\begin{array}{l}\text { The therapist } \\
\text { learn in } \\
\text { pronunciation }\end{array}$ & $\begin{array}{l}\text { The } \\
\text { therapist } \\
\text { works in } \\
\text { understand }\end{array}$ \\
\hline P1 & & & • $\ddot{\mathrm{u}}$ & & & \\
\hline P2 & & ••ü & & & & \\
\hline P3 & & • ü & & & & \\
\hline P4 & & • $\mathrm{u}$ & & & & \\
\hline P5 & & • $\ddot{\mathrm{u}}$ & & & & \\
\hline $\mathrm{P} 6$ & & & & • $\ddot{\mathrm{u}}$ & & \\
\hline P7 & & $\bullet \ddot{\mathbf{u}}$ & & & & \\
\hline P8 & • ü & • $\ddot{\mathrm{u}}$ & & & & \\
\hline P9 & & • $\ddot{\mathrm{u}}$ & & & • $\ddot{\mathrm{u}}$ & \\
\hline P10 & & • $\ddot{\mathrm{u}}$ & & & & • $\mathrm{u}$ \\
\hline P11 & & • ̈̈ & & & & • $\ddot{\mathrm{u}}$ \\
\hline $\mathrm{P} 12$ & & • $\ddot{\mathrm{u}}$ & & & & \\
\hline
\end{tabular}

[Note: Participant $=$ P And Number of participant P1, P2, P3, P4, P5, P6, P7, P8, P9, P10, P11 and P12]

Table 2. Category- 2: Parents experience about autism group therapy

\begin{tabular}{|c|c|c|c|c|c|}
\hline Code & $\begin{array}{l}\text { The therapy } \\
\text { Which is given } \\
\text { In a group of } 8-10 \text { child }\end{array}$ & $\begin{array}{l}\text { The therapy } \\
\text { which given } \\
\text { group }\end{array}$ & $\begin{array}{l}\text { The therapy } \\
\text { which work } \\
\text { together }\end{array}$ & $\begin{array}{l}\text { No re- } \\
\text { sponse }\end{array}$ & $\begin{array}{l}\text { The therapy which has many } \\
\text { children attend }\end{array}$ \\
\hline P1 & • $\ddot{\mathrm{u}}$ & & & & \\
\hline P2 & & • $\ddot{\mathrm{u}}$ & • ü & & \\
\hline P3 & & & & • ü & \\
\hline P4 & & & & & • $\ddot{\mathrm{u}}$ \\
\hline $\mathrm{P} 5$ & & • ü & & & • $\ddot{\mathrm{u}}$ \\
\hline P6 & & & & & • $\ddot{\mathrm{u}}$ \\
\hline P7 & $\ddot{\mathrm{u}}$ & & & & • ü \\
\hline P8 & & & & • ü & \\
\hline P9 & ü & & & & \\
\hline P10 & ü & & & & \\
\hline P11 & $\ddot{\mathrm{u}}$ & & & & \\
\hline P12 & & & • ü & & • ü \\
\hline
\end{tabular}

[Note: Participant $=$ P And Number of participant P1, P2, P3, P4, P5, P6, P7, P8, P9, P10, P11 and P12]

Table 3. Category- 3: Parents perception about autism group therapy previously

\begin{tabular}{|c|c|c|c|}
\hline Code & $\begin{array}{l}\text { Previous perception } \\
\text { absent }\end{array}$ & $\begin{array}{l}\text { Previous perception } \\
\text { present }\end{array}$ & $\begin{array}{l}\text { Therapist motivated for giving group therapy to the children's } \\
\text { mother }\end{array}$ \\
\hline P1 & & • $\ddot{\mathrm{u}}$ & \\
\hline P2 & & • $\ddot{\mathrm{u}}$ & \\
\hline P3 & - $\ddot{\mathrm{u}}$ & & \\
\hline $\mathrm{P} 4$ & • ü & & • $\ddot{\mathrm{u}}$ \\
\hline P5 & & • $\ddot{\mathrm{u}}$ & • $\ddot{\mathrm{u}}$ \\
\hline P6 & - ü & & - ü \\
\hline P7 & & - $\ddot{\mathrm{u}}$ & • $\ddot{\mathrm{u}}$ \\
\hline P8 & • $\ddot{\mathrm{u}}$ & & \\
\hline P9 & - $\ddot{\mathrm{u}}$ & & • $\ddot{\mathrm{u}}$ \\
\hline P10 & - $\ddot{\mathrm{u}}$ & & \\
\hline P11 & & - $\ddot{\mathrm{u}}$ & - $\ddot{\mathrm{u}}$ \\
\hline P12 & & • $\ddot{\mathrm{u}}$ & \\
\hline
\end{tabular}

[Note: Participant $=$ P And Number of participant P1, P2, P3, P4, P5, P6, P7, P8, P9, P10, P11 and P12] 
Table 4. Category-4: Parents knowledge about individual therapy

\begin{tabular}{|c|c|c|}
\hline $\begin{array}{l}\text { Code } \\
\text { P1 }\end{array}$ & $\begin{array}{l}\text { The Therapy which given by one therapist and one child } \\
\text { - } \ddot{\text { u }}\end{array}$ & No Response \\
\hline P2 & & • ü \\
\hline P3 & • $\ddot{\mathrm{u}}$ & \\
\hline $\mathrm{P} 4$ & • $\ddot{u}$ & \\
\hline P5 & • $\ddot{u}$ & \\
\hline P6 & - $\ddot{\mathrm{u}}$ & \\
\hline P7 & & • $\ddot{\mathrm{u}}$ \\
\hline P8 & • $\ddot{\mathrm{u}}$ & \\
\hline P9 & & • $\ddot{\mathrm{u}}$ \\
\hline P10 & • $\ddot{\mathrm{u}}$ & \\
\hline P11 & • $\ddot{u}$ & \\
\hline P12 & • $\ddot{\mathrm{u}}$ & \\
\hline
\end{tabular}

[Note: Participant $=\mathrm{P}$ And Number of participant P1, P2, P3, P4, P5, P6, P7, $\mathrm{P} 8, \mathrm{P} 9, \mathrm{P} 10, \mathrm{P} 11$ and $\mathrm{P} 12]$

Table 5. Category-5: The parents which are given therapy for their children by therapist

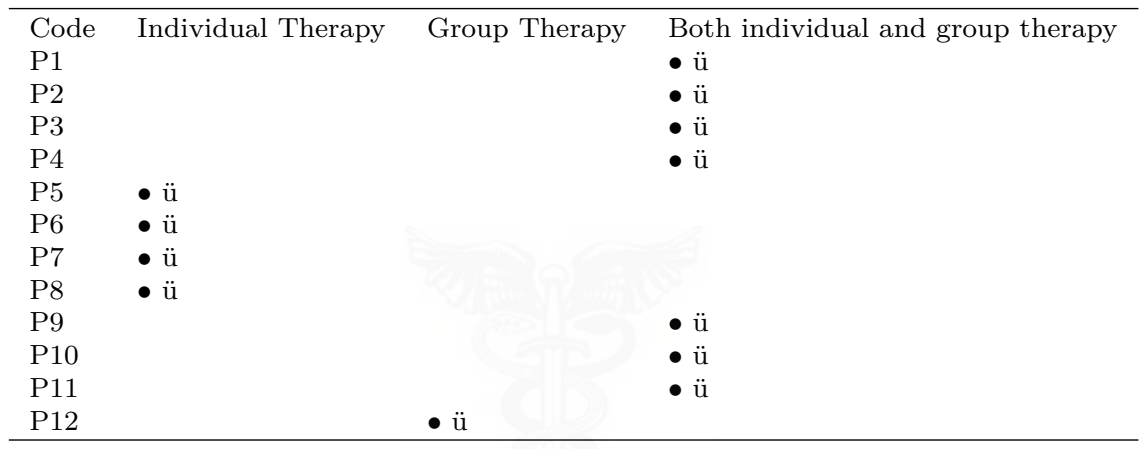

Note: Participant $=$ P And Number of participant P1, P2, P3, P4, P5, P6, P7, P8, P9, $\mathrm{P} 10, \mathrm{P} 11$ and P12]

where children play one to another in children. One participants (P11) mentioned that the therapist learning in object introduces for knowing in different types of object, four participants (P4, P6, P7, P9) also mentioned that their children learned that body parts point but only one participant $(\mathrm{P} 4)$ said that colors (e.g: red, blue, green) introducing learned.

List of the Table 8 finds that the maximum participants (P1, P2, P4, P5, P6, P10, P11 and P12) indicated as few improvements after taking autism group therapy. On the other hand, five participants (P1, P2, P3, P8 and P9) expressed as many improved in autism group therapy. But one participant said that do not improve the child in group therapy.

Table 9 reveals that the maximum participants $(\mathrm{P} 1, \mathrm{P} 2$, P3, P4, P6, P8, P9, P10 and P11) did not face to give group therapy to their children. The minimum participants (P8 and P12) said that "everything is clear to give group therapy to their children in speech and language therapist." But Participant P-7 said that she faced some problem in group therapy because the child was very excited in group therapy.

According to the Table 10, the nine participants mentioned that the expectation of normal life for their children from autism group therapy and the five participant's expectation of regaining speech from autism group therapy. But the minimum parents ( $\mathrm{P} 1$ and $\mathrm{P} 6)$ expectation of complete care of their child from group therapy in speech and language therapy and P-1, P-5 said that the child will better improvement.

Six parents suggested increasing the time. Other five participants noted as appropriate about the autism group therapy. Four participants suggested increasing therapy time to make successful about autism group therapy. The P-3 is also agreed that "if the therapist wants children more improvement, they need to differentiate between improvement and un-improvement child in autism group therapy.

\subsection{Results major themes emerged from the study:}

Theme 1: Parents knowledge about speech and language therapy was the therapy to learning speaking, the therapist works to understand.

Theme 2: Parents experience about autism group therapy was the therapy which has many children attends and given in a group of 8-10 children, the therapy which has given group and works together.

Theme 3: Parents were a previous perception present, absent about autism group therapy and therapist motivated for giving group therapy to the children's mother.

Theme 4: Parents knowledge about individual therapy was the therapy given by one therapist and one child. 
Table 6. Category-6: Therapy is given in different types of group therapy in your children

\begin{tabular}{|c|c|c|c|c|c|}
\hline \multirow{3}{*}{$\begin{array}{l}\text { Code } \\
\text { P1 }\end{array}$} & \multicolumn{5}{|c|}{ Social $\quad$ Preverbal Language Therapy } \\
\hline & Interac & tibse music for increase attention & Sharing & Eye Contact & Rhymes \\
\hline & & $\bullet \ddot{\mathrm{u}}$ & & & \\
\hline P2 & • $\ddot{\mathrm{u}}$ & - $\ddot{\mathrm{u}}$ & & & • $\ddot{\mathrm{u}}$ \\
\hline P3 & & • $\ddot{\mathrm{u}}$ & & & - ü \\
\hline $\mathrm{P} 4$ & & & & & \\
\hline P5 & - ü & - ü & & & \\
\hline P6 & & & & & \\
\hline P7 & - $\ddot{\mathrm{u}}$ & - $\ddot{\mathrm{u}}$ & - ü & & \\
\hline P8 & • ü & • ü & & & \\
\hline P9 & • ü & • ü & • $\ddot{\mathrm{u}}$ & • ü & • $\ddot{\mathrm{u}}$ \\
\hline P10 & - ü & - ü & & & - $\ddot{\mathrm{u}}$ \\
\hline P11 & • $\ddot{\mathrm{u}}$ & • $\ddot{\mathrm{u}}$ & & • ü & • $\ddot{\mathrm{u}}$ \\
\hline P12 & • $\ddot{\mathrm{u}}$ & - ü & - ü & & - $\ddot{\mathrm{u}}$ \\
\hline
\end{tabular}

Note: Participant $=$ P And Number of participant P1, P2, P3, P4, P5, P6, P7, P8, P9, $\mathrm{P} 10, \mathrm{P} 11$ and P12]

Table 7. Category-6: Therapy is given in different types of group therapy in your children

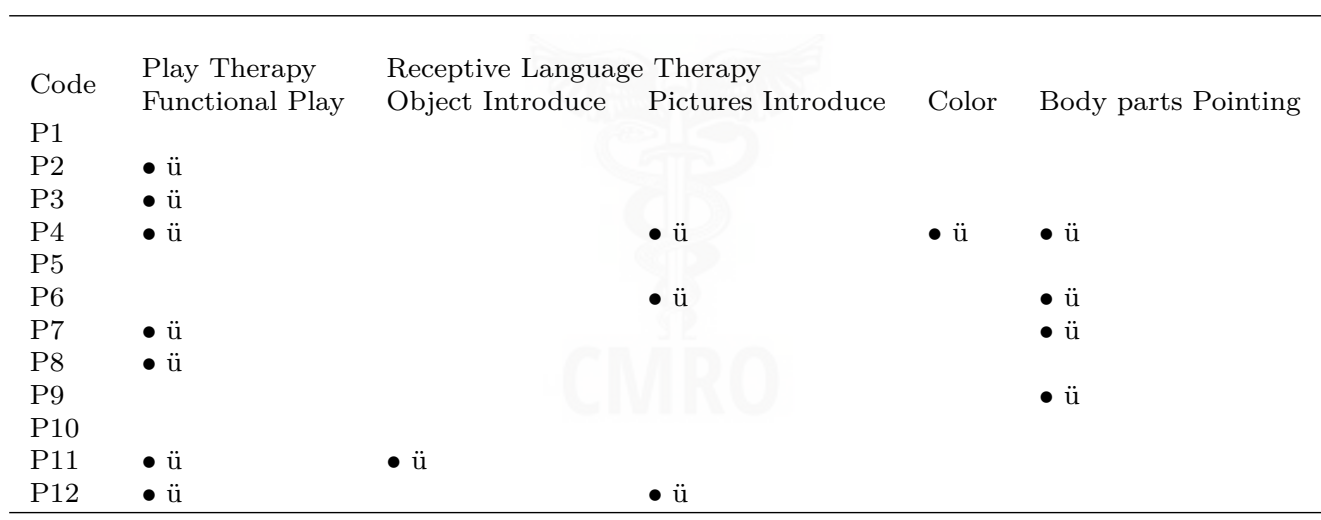

Note: Participant $=$ P And Number of participant P1, P2, P3, P4, P5, P6, P7, P8, P9, P10, P11 and $\mathrm{P} 12]$

Table 8. Category-7: Improvement of the patients after taking autism group therapy from speech and language therapy

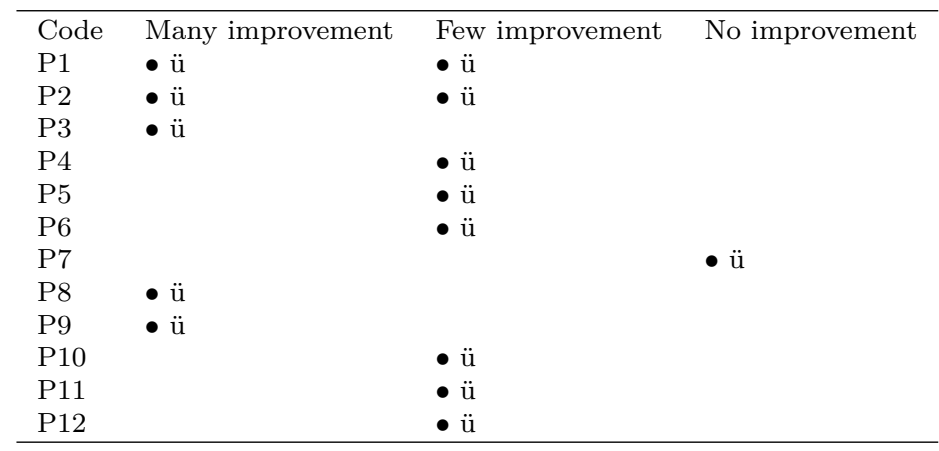

Note: Participant $=$ P And Number of participant P1, P2, P3, P4, P5,

$\mathrm{P} 6, \mathrm{P} 7, \mathrm{P} 8, \mathrm{P} 9, \mathrm{P} 10, \mathrm{P} 11$ and P12] 
Sharmin Sultana et al.

Table 9. Category-8: During group therapy which parents faced problem to their children.

\begin{tabular}{llll}
\hline Code & Did not face Problem & All is perfect & Limited problem faced \\
P1 & $\bullet \ddot{\mathrm{u}}$ & & \\
P2 & $\bullet \ddot{\mathrm{u}}$ & & \\
P3 & $\bullet \ddot{\mathrm{u}}$ & & \\
P4 & $\bullet \ddot{\mathrm{u}}$ & & \\
P5 & $\bullet \ddot{\mathrm{u}}$ & & \\
P6 & $\bullet \ddot{\mathrm{u}}$ & $\bullet \ddot{\mathrm{u}}$ & \\
P7 & & & \\
P8 & $\bullet \ddot{\mathrm{u}}$ & & \\
P9 & $\bullet \ddot{\mathrm{u}}$ & & \\
P10 & $\bullet \ddot{\mathrm{u}}$ & $\bullet \ddot{\mathrm{u}}$ & \\
P11 & $\bullet \ddot{\mathrm{u}}$ & & \\
P12 & &
\end{tabular}

Note: Participant $=$ P And Number of participant P1, P2, P3, P4, P5, P6, P7, P8, P9, P10, P11 and P12]

Table 10. Category-9 : Attitude of parent for their children after giving autism group therapy

\begin{tabular}{|c|c|c|c|c|}
\hline Code & $\begin{array}{l}\text { Expectation of regain } \\
\text { speech }\end{array}$ & $\begin{array}{l}\text { Expectation of normal } \\
\text { life }\end{array}$ & $\begin{array}{l}\text { Expectation of completely } \\
\text { care }\end{array}$ & $\begin{array}{l}\text { Expectation of better } \\
\text { improvement }\end{array}$ \\
\hline P1 & & & • $\ddot{\mathrm{u}}$ & • $\ddot{\mathrm{u}}$ \\
\hline P2 & • $\ddot{\mathrm{u}}$ & • ü & & \\
\hline P3 & & • $\ddot{\mathrm{u}}$ & & \\
\hline P4 & • $\mathrm{u}$ & • $\mathrm{u}$ & & \\
\hline P5 & & & & • $\ddot{\mathrm{u}}$ \\
\hline P6 & & & • $\ddot{\mathrm{u}}$ & \\
\hline P7 & & • $\mathrm{u}$ & & \\
\hline P8 & & • $\mathrm{u}$ & & \\
\hline P9 & • $\ddot{\mathrm{u}}$ & • $\mathrm{u}$ & & \\
\hline P10 & • $\ddot{\mathrm{u}}$ & • $\mathrm{u}$ & & \\
\hline P11 & & • $\ddot{\mathrm{u}}$ & & \\
\hline P12 & • $\mathrm{u}$ & • $\mathrm{u}$ & & \\
\hline
\end{tabular}

Table 11. Category-10: Parents suggestion to make successful about autism group therapy

\begin{tabular}{|c|c|c|c|c|}
\hline Code & $\begin{array}{l}\text { Need therapy more days in } \\
\text { month }\end{array}$ & $\begin{array}{l}\text { Appropri- } \\
\text { ate }\end{array}$ & $\begin{array}{l}\text { Need to difference between improvement child and } \\
\text { un-improvement child }\end{array}$ & $\begin{array}{l}\text { Increase } \\
\text { time }\end{array}$ \\
\hline P1 & • $\ddot{\mathrm{u}}$ & & & \\
\hline P2 & & • $\ddot{\mathrm{u}}$ & & \\
\hline P3 & & • $\ddot{\mathrm{u}}$ & - ü & \\
\hline $\mathrm{P} 4$ & & • $\ddot{\mathrm{u}}$ & & \\
\hline P5 & & & & - ü \\
\hline P6 & & • $\ddot{\mathrm{u}}$ & & \\
\hline P7 & & • $\ddot{\mathrm{u}}$ & & \\
\hline P8 & & & & • $\ddot{\mathrm{u}}$ \\
\hline P9 & • $\ddot{\mathrm{u}}$ & & & • $\ddot{\mathrm{u}}$ \\
\hline P10 & & & & - $\ddot{\mathrm{u}}$ \\
\hline P11 & • $\ddot{\mathrm{u}}$ & & & • $\ddot{\mathrm{u}}$ \\
\hline $\mathrm{P} 12$ & • $\ddot{\mathrm{u}}$ & & & • $\ddot{\mathrm{u}}$ \\
\hline
\end{tabular}

Theme 5: The parents were given an individual and both individual and group therapy for their children by the therapist.

Theme 6: Parents described therapist is given in different types of group therapy in her children such as social interaction, use music for increase attention; learn Rhymes, functional play, sharing, eye contact, body parts pointing and pictures introduce.

Theme7: Many and few improvements after taking autism group therapy from speech and language therapy.

Theme 8: Group therapy parents did not face a problem and all was perfect for their children
Theme 9: Parents was expected of normal life, of regaining speech, of better improvement for their children after giving autism group therapy

Theme 10: Parents suggestions to increase time, to need therapy more days in a month.

\section{DISCUSSIONS:}

In this study, 10 questions were asked among 12 parents of the children with ASD. Answered question from the participants were 11 categorized. From the 11 categories richer 


\section{Group Therapy Perception among Parents of ASD Children Attended At SLT Unit in a Reputed Rehabilitation Centre

found 10 important themes. Speech and language therapy (SLT) is an effective health profession where the therapeutic practice of speech is used for special needs children. Children are treated by play activities. This health profession has a great role for children with attention, socialization, behavior, communication problem thus they offer this child for therapy by arranging a group.

Autism group therapy is the place where children are guided by the speech therapist. In the response of the meaning of speech therapy, the participant is able to say the common concept. They have a general knowledge of speech and language therapy. Most of the parents think SLT is understood and learning speaks. On the second category, participants experienced about autism group therapy were the therapy where many children attended in a group of 8-10 children. Group therapy involves one or two therapists who lead a group of roughly five to eight parents and child [10]. In this category, five participants explained that group therapy stayed more children. On the third category, the theme that came out was previous perception absent about autism group therapy and therapist motivated for giving group therapy to the children's mother. As autism group therapy is a new concept in Bangladesh, so more mother does not know about group therapy. Although a few mothers came in CRP for individual therapy, they do not know about group therapy. Murray et al. (2009) [11] stated that the participants were referred by a therapist for group therapy. The therapist motivated to parents for autism group therapy. The six theme results in this study revealed that the group therapy was given by the therapist were socialization, learn Rhymes, sharing, body parts pointing and pictures introduce. White et al. (2007) [12] reported that social interaction, communication are needed for autism child due to their hyper activeness. According to Charman et.al (1997) [8], Children with autism provided group therapy including pretend play, joint attention. Generally, the child likes play activities. So therapists arranged play therapy for increasing children attention. Whalen \&Schreibman (2003) [13] stated that Joint attention is effective for the correct response. Play music therapy was also significant between-group differences for joint attention with peers and eye gaze towards persons [14]. Some participants mentioned that music therapy is used for increasing attention. Few patients were improved by autism group therapy from speech and language therapy. Antshel et al. (2011) [15] stated that patient improving in social and functioning skills by group intervention. The eight categories results indicated that parents did not face any problem during group therapy Participants- 8 reported to facing some problem for group therapy because the child was very excited in group therapy. During treatment effective interaction and families counseling is needed by speech and language therapist. Participants 6 suggested increasing therapy time. One of the participants explained, "I think the time is not sufficient at all, as one hour of treatment is not good for us and need more time to practice." But Patients have an allocated time of day to get service. On the other hand, 5 of the participants thought the time provided by the SLT professional were sufficient.

\section{CONCLUSION:}

It is concluded that group therapy which is provided by speech and language therapists is a wide treatment media for children with autism. Parents' perception of group therapy is improving their child. However, most of them are motivated by group therapy. At the end of the study, the results show that parents are able to gain knowledge about group therapy for their children. They are able to express the perception of group therapy and thus they provide some recommendations about group therapy which will help both therapist and children who took in autism group therapy.

Acknowledgement: The author would like to thank all participants and also acknowledge the support provided by the Department of Speech and Language Therapy at Bangladesh Health Professional Institute (BHPI), Savar, and the State College of Health Sciences (SCHS), Dhaka, Bangladesh.

Conflict of Interest: The authors of the article declare that there are no ethical conflicts regarding this article.

Disclosure of Benefits: No funding was received from any organizations

\section{REFERENCES}

1. Michael. D and Powers. (2000). Children with autism: A parent's guide (2nd edn).United states of America.

2. American Speech-Language-Hearing Association (2010).Prevalence of autism. Retrieved from:

http://www.asha.org/PRPSpecificTopic.aspx?folderid $=858$

3. Ruble L.A., Dalrymple N.J., and McGrew J.H. (2010). The Effects of Consultation on Individualized Education Program Outcomes for Young Children with Autism: The Collaborative Model for Promoting Competence and Success. J Early Interv. 32 (4): 286-301. doi: 10.1177/1053815110382973

4. Centers for Disease Control \& Prevention (CDC) (WHO, 2016). Retrieved from:

https://www.who.int/vaccine_safety/initiative/communication/ network/nip/en/

5. Kim Y.S., Leventhal B. L., Koh Y. J. Fombonne, E. Laska, E. Lim, E.C.et.al. (2011). Prevalence of autism spectrum disorders in a total population sample. The journal of American Psychiatric Association. doi: 10.1176/appi.ajp.2011.1010153 6. Jordan R. \& Jhons G. (1999)."Meeting the need of children with autistic spectrum disorder."USA: British Library Cataloging in Publication.

7. Ellis, K. (1999). Autism: Professional perspectives and practice in London: British Publised in Association with the National autistic society.

8. Charman T., Swettenham J. and Baron-Cohen S. (1997). Infants with autism: an investigation of empathy, pretend play, joint attention, and imitation. The journal of American psychological association developmental psychology. 33 (5):781-789.

9. Hicks C.M. (2000)."Research methods for clinical Therapists: applied project design and analysis (3rdedn.). "British library cataloguing in Publication.

10. American psychological association. (2016). Understanding group therapy. Retrieved from http://www.apa.org/helpcenter/ group-therapy.aspx

11. Murray D.S., Ruble L.A., Willis H. and Molloy C. A. (2009). Parent and teacher report of social skills in children with autism spectrum disorders. American Speech-Language-Hearing Association.40: 109-115, doi:10.1044/0161-1461(2008/07-0089) 
12. White S.W., Keonig K and Scahill L. (2007). Social skills development in children with autism spectrum. The journal of autism developmental disorder. 37:1858-1868.

DOI:10.1007/s10803-006-0320-x

13. Whalen C. and Schreibman L. (2003).Joint attention training for children with autism using behavior modification procedures. The journal Child Psychology and Psychiatry, Retrieved 44(3) : 456- 468. Retrieved from http://atcnts.com/wp-content/uploads/Joint-attentiontraining-for-children-with-autism-using-behavior-modi\%C2\%

A2cation-procedures.pdf.

14. La Gasse A. B. (2014). Effects of a music therapy group intervention on enhancing social skills in children with autism. The journal of American music therapy association.51 (3): 250-275. doi: 10.1093/jmt/ thu012

15. Antshel K.M., Polachek C., McMahon M., Dygert K. et al. (2011). Comorbid ADHD and anxiety affect social skills group intervention treatment efficacy in children with autism spectrum disorders. The journal of developmental \&behavioral pediatrics. 32(6). Doi: 10.1097/ DBP.0b013e318222355d. 